\title{
An Assessment Of Clean Development Mechanism Project Contribution To Sustainable Development In Nigeria
}

\author{
Dr. Surendran Pillay, University of Kwa-Zulu Natal, South Africa
}

\begin{abstract}
A Clean Development Mechanism (CDM) is a market-based climate change instrument used to reduce emissions of greenhouse gases. CDM's have become popular in many developing countries, however given the materially skewed distribution of CDM projects in developing countries it not clear whether CDM projects contribute materially to environmental and economic sustainable development in developing countries. This study examines the effect of CDM on sustainable development in Nigeria by reviewing sample of working CDM projects in Nigeria against globally established sustainable development criteria. Possible amendments to CDM policy are then reviewed based on the findings made during the study.
\end{abstract}

Keywords: Climate Change; Clean Development Mechanism; Certified Emission Reductions; Greenhouse Gas Emissions; Sustainable Development

\section{INTRODUCTION}

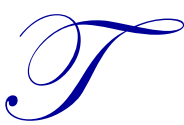
he United Nations Framework Convention on Climate Change (UNFCCC) was established in 1992 with the objective of lowering greenhouse gas emissions (UNFCCC, 2004). Nigeria signed the UNFCCC in November 2004. (UNFCCC, 2015). Nigeria's carbon emissions (these emissions stem from the burning of fossil fuels and the manufacture of cement and include carbon dioxide produced during the consumption of solid, liquid and gas fuels) was 0.5 metric tons per capita (Worldbank, 2015). This emission level is much higher than many other African countries such as Kenya ( 0.33 metric tons per capita) and Cameroon ( 0.32 metric tons per capita) (EC, 2015).

Linked to the UNFCCC is the Kyoto protocol which was signed by industrial countries in 2007(Kyoto, 2010). The Kyoto protocol places an obligation on nations to lower their greenhouse gas emissions in comparison to 1990 emission levels (Kyoto, 2010). Kyoto protocol instruments to reduce greenhouse gases include "cap and trade" schemes as well as clean development mechanisms "CDM" (UNFCCC, 2015b). Nigeria became a signatory of the Kyoto protocol in December 2004 (NG, 2015) and is currently listed as a non-annexure 1 country to the protocol (UNFCCC, 2015a).

The measure or obligations in place for non-annexure 1 countries are significantly lower than annexure 1 countries as the measures of compliance for a non-annexure 1 country is to report on deviations from the 1990 carbon emissions target.(Von Stein, 2005) Annexure 1 countries are allowed to achieve some emissions reductions by cutting in energy and tree planting activities that cut GHG emissions in developing countries (OR non-annexure 1 countries) through clean development mechanisms (Santilli, et al., 2005). Nigeria being a non-annexure 1 country to the Kyoto protocol is involved in various CDM projects (CDM, 2015)

A CDM is a project that allows industrialised countries that are subject to emission reduction targets to develop or finance projects that reduce greenhouse gas (GHG) emission in non-Annex 1 countries 1 in exchange for emission reduction credits (Dechezleprêtre et al.,2008). A CDM project thus reduces carbon emissions through an agreement between an emitter in a developed country and a project owner in a developing country such that the emitter provides infrastructure and capital to the project owner in the developing country to the amount of carbon credit generated by the project owner in the developing country. This credit which is often referred to as a certified emission reduction or 
"CER" is then used by the emitter in the developed country (DEAT, 2010). CDM was first established on 11 December 1997 as part of the Kyoto Protocol (Lecocq \& Ambrosi, 2004).

In terms of Article 12 of the Kyoto Protocol the broad goals of the CDM is to assist developing countries to the Kyoto Protocol to achieve sustainable development as well as to assist developed country parties to the Kyoto Protocol in achieving compliance with part of their emission reduction commitment under Article 3 of the Kyoto Protocol (Streck, 2004). The specific objectives of a CDM project are to aid developing countries in achieving outcomes such as poverty reduction, cost-effective emissions reductions as well as environmental benefits thus contributing towards sustainable development (Zomer et al.,2008). Since the CDM requires approval from all participating parties it effectively establishes a platform for cooperation between annexure 1 and non-annexure 1 countries (Streck, 2004).

\section{Alternative Market-Based Instruments}

Market-based instruments such as carbon tax and cap and trade schemes remain the alternatives to CDM projects (UNFCCC, 2004). Cap and trade schemes were established under the UNFCCC in 2004 and operate through the issuance by governments of permits to emit greenhouse gases to industrial companies. These permits or licenses can be exchanged in a carbon market thus allowing under polluters to effectively sell under-utilised carbon credits to over polluters (UNFCCC, 2004 \& Gilbertson \& Reyes, 2009). The largest cap and trade scheme in the world is the EU Emission Trading System "EU-ETS" which covers more than 11,000 power stations in 31 countries as well as airlines (EC, 2015a).

A second market-based alternative to CDM is a carbon tax which is a tax on carbon emissions for the purpose of internalising any associated externalities in relation to anthropogenic climate change (Metcalf and Weisbach, 2009). In terms of economic sustainable development, various academic studies have confirmed carbon tax to be possibly regressive in nature (Pillay \& Buys, 2013).

\section{SUSTAINABLE DEVELOPMENT}

The broad goals of CDM are to achieve sustainable development in terms of the Kyoto Protocol (Streck, 2004).

The definition of sustainable development arose from the Brundland report in 1987 and has been defined as Development that] meets the needs of the present without compromising the ability of future generations to meet their own needs" (Brundtland et al., 1987). Sustainable development may be divided into three parts, the environmental, the social and the economic, which is known as the triple bottom line (Newport et al, 2003).

While economic sustainability refers to the ability to support a defined level of economic output for an indefinite time period (Anon, 2015), social sustainable development has been defined as growth that is compatible with the evolution of civil society, fostering an environment conducive to the compatible cohabitation of culturally and socially diverse groups while at the same time encouraging social integration, with improvements in the quality of life for all segments of the population. (Bramley et al, 2006). Social sustainable development would also encompass principle such as gender and race equity, empowerment of socially disadvantaged groups and as well as cultural preservation (Worldbank, 2015a). Environmental sustainable would encompass the maintenance of natural resources, biodiversity, clean air and water as well as the integrity of the ecosystem (Worldbank, 2015a).

\section{CDM Projects in Nigeria}

A requirement for a project activity to be registered with the UNFCCC as a CDM project, is the submission of a CDM project activity form as well as the payment a registration fee by the designated operational entity (CDM, 2015a). In 2015, CDM projects in Nigeria totalled approximately 12 projects covering activities such as landfill gas, hydro, biomass energy and fugitive emission reductions (CDM, 2015). Project concentration is on landfill gas and fugitive emission reduction projects (CDM, 2015).

In terms of the assessment of CDM projects, the predominant method of assessing the contribution of CDM project toward sustainable development is to examine the underlying project design document of the CDM projects (Pillay and Buys, 2013). A review of CDM projects by country and regions confirms that projects are unequally distributed 
amongst the developing nations of the worlds (CDM, 2015). The question then becomes can CDM effectively contribute to economic sustainable development in Nigeria.

\section{RESEARCH PROBLEM AND METHOD}

This paper explores the potential impact of CDM projects on economic and environmental sustainable development in Nigeria. The research problem question could thus be framed as follows:

P1 - Does CDM effectively contribute to sustainable development in Nigeria?

The research can be described as an exploratory literature study in determining the impact of CDM projects on economic and environmental sustainable development in Nigeria. An overview of the effect CDM projects internationally on sustainable development is first completed and then skewness of the distribution of CDM projects in Nigeria is then considered. An assessment of 10 working CDM projects in Nigeria will then be carried out in order to determine the economic and environmental sustainable development contribution of such projects according to sustainable development criteria.

\section{INTERNATIONAL OVERVIEW OF CDM PROJECTS}

There are 7681 internationally registered CDM projects as at December 2015 with approximately 2583 projects having received certified emission reductions (CDM, 2015).

Table 1. International Distribution of CDM projects

\begin{tabular}{l|l|c|c}
\hline \multicolumn{1}{c|}{ No } & \multicolumn{1}{|c|}{ Region } & Number & Proportionate \% per region \\
\hline 1 & Latin America & 991 & $13 \%$ \\
\hline 2 & Asia \& Pacific & 6333 & $82 \%$ \\
\hline 3 & Europe and Central Asia & 73 & $1 \%$ \\
\hline 4 & Africa & 199 & $3 \%$ \\
\hline 5 & Middle East & 85 & $1 \%$ \\
\hline & Total & 7681 & $100 \%$ \\
\hline
\end{tabular}

Source: (CDM, 2015)

The international distribution of CDM projects as represented in table 1 above is heavily skewed toward the Asia and Pacific region which accounts for approximately $82 \%$ of all CDM projects globally. The lowest distribution of CDM project remains with the Europe and Central Asia region as well as the Middle East region. Both regions only account for $1 \%$ of all $\mathrm{CDM}$ projects globally. The Africa region even though comprising a large number of developing countries only hosts $199 \mathrm{CDM}$ projects and accounts for only $3 \%$ of all CDM projects globally.

\section{CDM CONTRIBUTION TO SUSTAINABLE DEVELOPMENT}

\section{Environmental Considerations}

Various studies across the world have been conducted in examining the impact of CDM projects on greenhouse gas emissions:

- A study comparing the effectiveness of CDM projects and international emissions trading systems confirmed that CDM will be more effective than international emissions trading in implementing the Kyoto Protocol (Woerdman, 2000).

- An evaluation of the overall effectiveness of CDM projects acknowledges that the CDM is effective in providing certified emission reductions, however, the inequitable geographical distribution of projects and lack of sustainable development benefits are still problematic (Paulsson, 2009)

- Rai (2009:70) confirms that CDM has successfully channelled funding many projects that reduce the emissions of greenhouse gases but has also spawned various projects with minimal environmental benefits. 
Graph 1. CDM impact on Emissions Reductions

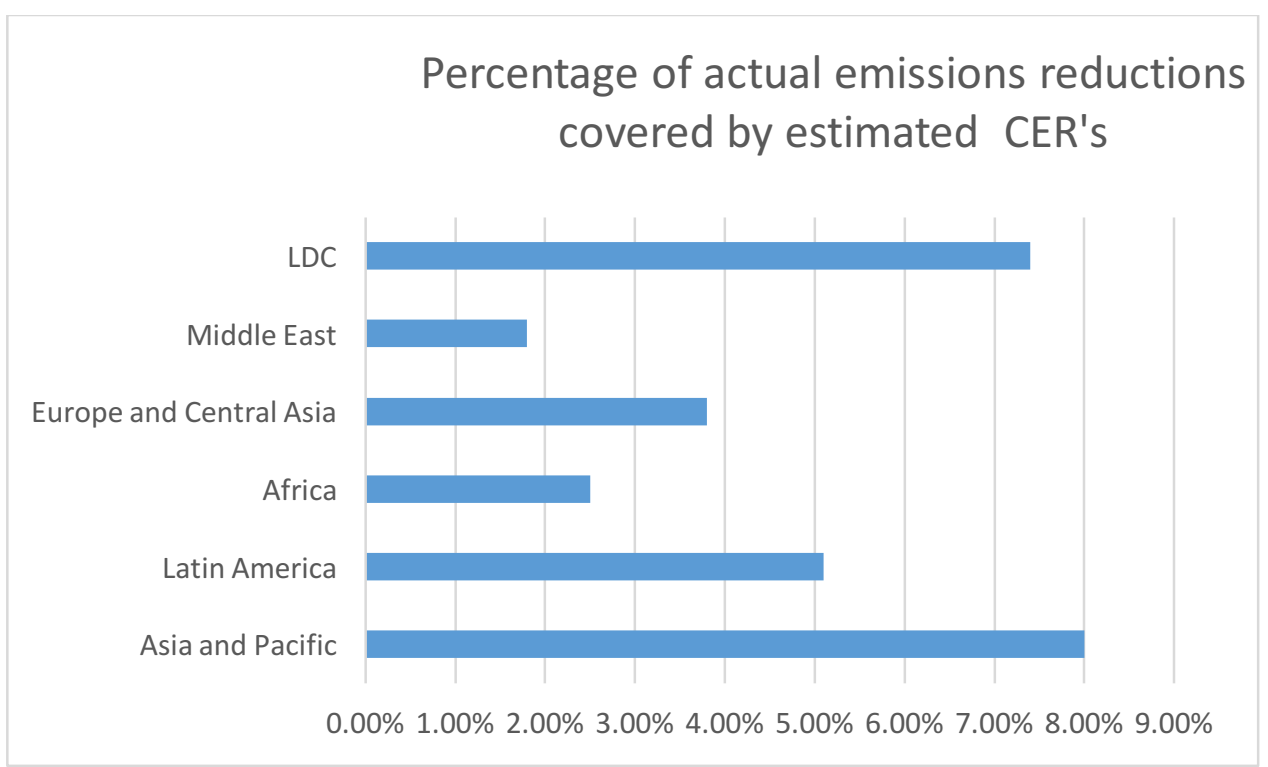

Source: CDM, 2015

CDM effectiveness in reducing actual greenhouse gases on a global basis is measured by comparing the estimated certified emission reductions from CDM projects against the actual greenhouse gas emission reduction for each region in the world. In terms of CDM project effectiveness, the Asia and Pacific region had approximately $8 \%$ of their total actual emission reductions covered by CDM CER's resulting in CDM's being most effective in this region. CDM projects appeared to have been least effective in the Middle East region where CER's covered only $1.8 \%$ of actual emission reductions. A total of $2.5 \%$ of actual emission reductions is covered by CDM CER's in Africa which results in the region being placed of $5^{\text {th }}$ overall in the world in terms of CDM effectiveness in emission reductions.

\section{Economic Considerations}

In terms of economic sustainable development, the effect of CDM on economic sustainable development has been researched with mixed findings. The results of these studies are summarised below:

- In a study of 10 working CDM projects distributed globally no causal relationship could be established between project types and sustainable development outcomes with many cases offering little direct employment opportunities (Boyd et al, 2009).

- A study on the impact of CDM on the power sector in China confirms that CDM projects cause net direct job loss of 99000 but also create 3.08 million indirect job opportunities resulting in a significant net increase in employment in China (Wang et al, 2013).

- A study performed on 10 working CDM projects in South Africa confirmed that CDM is heavily skewed toward GHG reduction with little priority being given to employment generation and economic sustainable development (Pillay, 2015).

The above studies confirm that the impact of CDM projects on the economic sustainable development of many regions around the world including Nigeria is still uncertain. 
Graph 2. Macroeconomic Contribution of CDM

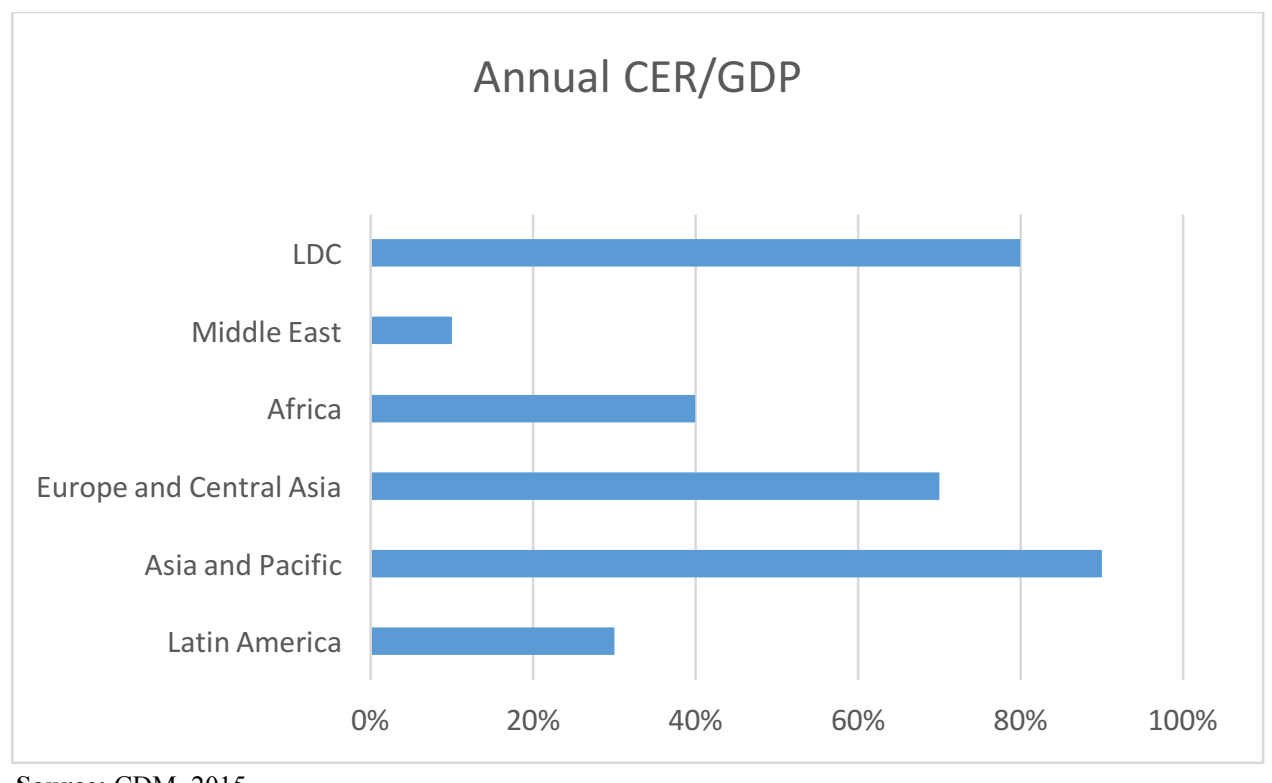

Source: CDM, 2015

The economic sustainability of CDM in any particular region is also measured by the value of CER's generated by CDM projects in the region relative to the combined GDP of the region. Graph 2 provides a high level overview of the macro-economic contribution of CDM to regional economies of the world.

An analysis of graph 2 reveals that CDM is most economically significant in the Asia and Pacific region where it CER's generated and accounted for more than $80 \%$ of the regional GDP. In Africa CER's generated by CDM only account for $40 \%$ of the regional GDP of the African region. The African region is placed fourth overall out of 6 regions in terms of CDM contribution to the economy. In Nigeria CER's arising from CDM projects account for $44.87 \%$ of the GDP which is slightly higher than the overall average of $40 \%$ for the African region. The graph above confirms the positive economic sustainability effects of implementing CDM projects around the world.

\section{CDM PROJECT ANALYSIS IN NIGERIA}

UNEP have confirmed a total number of 12 CDM projects in Nigeria in 2015 with these projects spread across different industries and engaged in different project activities (CDM, 2015). The distribution of CDM projects by project type is an important indicator in determining the effectiveness of CDM projects as a whole in contributing to economic and environmental sustainable development as the more unequal the distribution the more debateable their contribution to sustainable development becomes (Boyd et al., 2009). 
Graph 3. CDM Project Distribution by Project Type in Nigeria

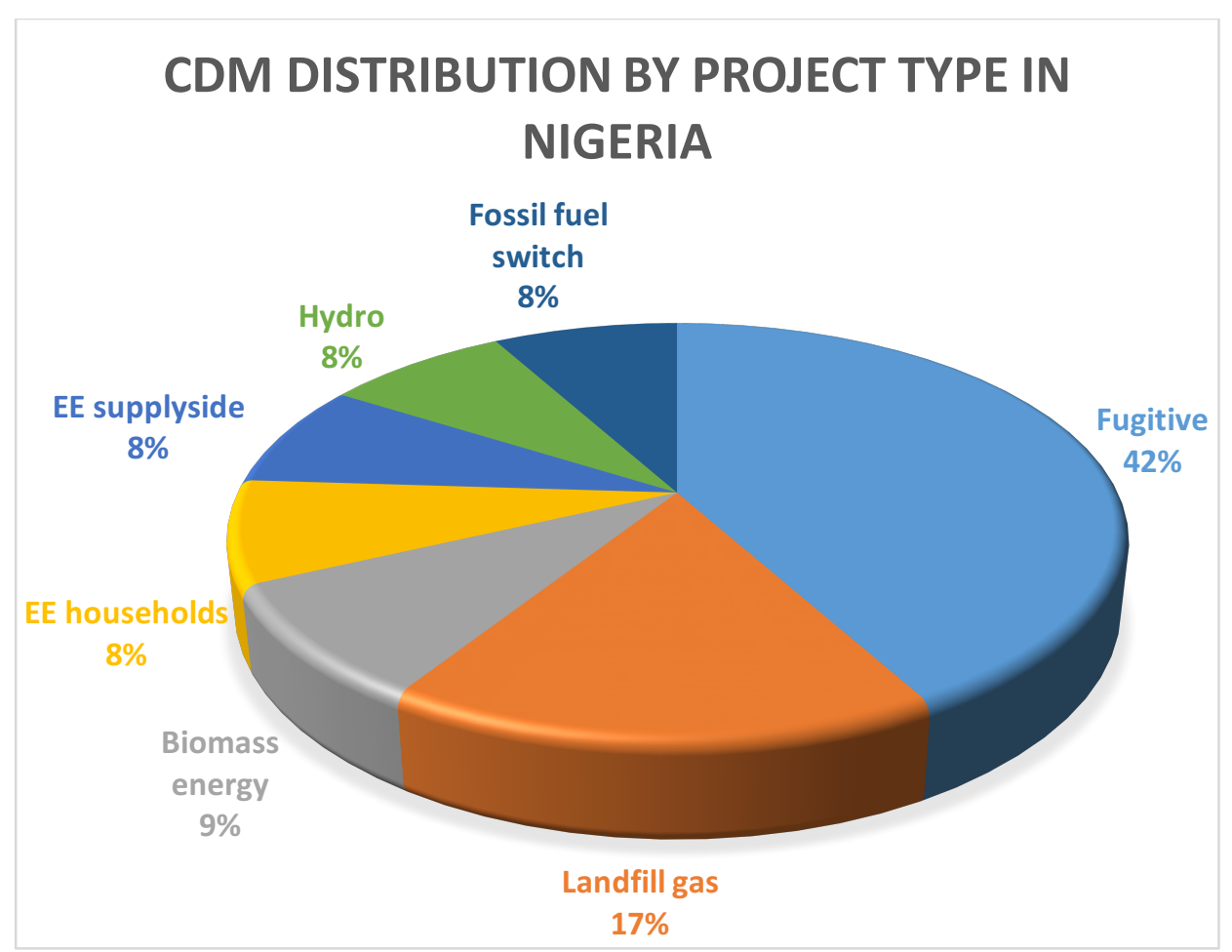

Source: CDM, 2015

As noted in Graph 3, Nigeria hosts a total of 7 different types of CDM projects within its provinces with the most common technology being fugitive emissions reduction projects and landfill gas projects. Fugitive emission reduction projects and landfill gas projects collectively represent $59 \%$ of all CDM projects in Nigeria. The least number of CDM projects are in electrical energy projects and fossil fuel switch projects. Since there are 7 different project types with two CDM project types constituting 59\% of all CDM projects, it appears the CDM project distribution is unequal. 
Graph 4. CDM Project Distribution by Geographic Region in Nigeria

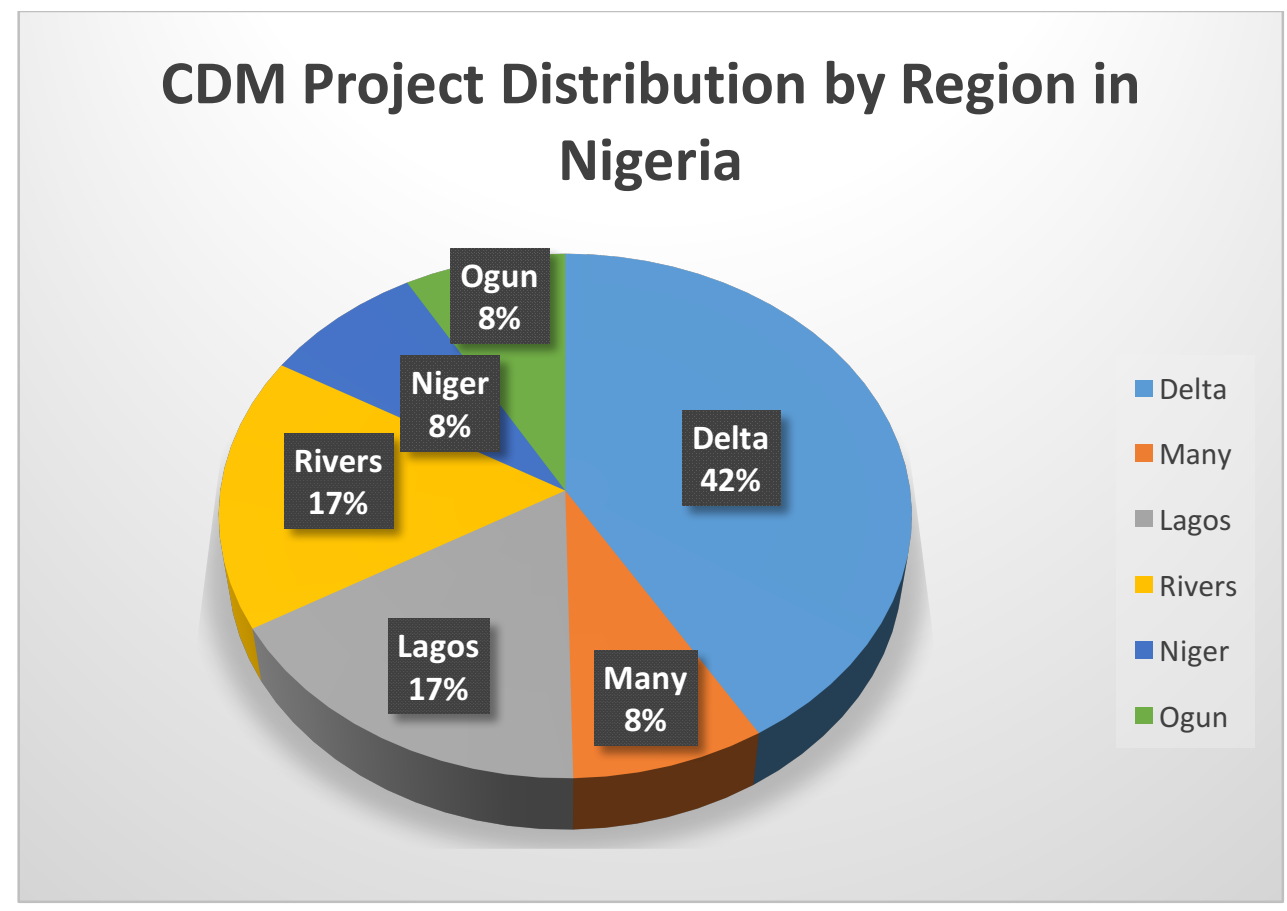

Source: CDM, 2015

As noted in Graph 4, approximately $42 \%$ of CDM projects in Nigeria are in the Delta region. A further $34 \%$ of projects are located in Lagos and the Rivers region. The lowest geographic region with CDM projects is Niger, Many and Ogun which each hold $8 \%$ of the total CDM projects in Nigeria. Given that close to half of all CDM projects are located in the Delta region of the country one may conclude that distribution of CDM projects by region in Nigeria is also uneven.

\section{Sustainable Development Assessments of CDM In Nigeria}

The impact of CDM projects on sustainable development in various countries have been performed with reference to an examination of the underlying project design documents (PDD's) of a CDM project. Studies by Pillay (2015) as well as Sutter \& Parreno (2007) have reviewed the underlying PDD's in order to assess the impact of CDM projects on sustainable development. A project design document present information of important technical aspects of the project activity and is a key input into the registration of the project under the Kyoto protocol (CDM, 2015b).

\section{CDM Assessment in Nigeria}

A common method for evaluating the contribution of CDM projects to sustainable development is to examine the supporting project design documents (PDD's) in order quantify or assess the contribution of a project toward sustainable development. This method has been used extensively by Sirohi (2007) as well as (Boyd, et al, 2007) in determining the sustainable development impact of a project. A sample of 10 projects selected according to project type as well distribution, with the supporting project design documents then being examined for detailed review. The detailed review entails evaluating the projected sustainable development benefits against sustainable development criteria. These criteria would include health, technology transfer benefits as well as employment and emissions reduction criteria. The objective of the CDM evaluation is to provide a broad overview of the projects contribution toward sustainable development.

In terms of the actual evaluation of projects, "direct benefit" would refer to benefits that immediately manifest from the project while indirect benefits are expected to only manifest at a later stage through the occurrence of a direct benefit. An example could be a reduction in greenhouse gases which would provide an indirect health benefit (in terms 
of the lower incidence of diseases caused by greenhouse gases). Project benefits that are not material are classified as a negligible benefit.

Key:

$\checkmark \checkmark$ - direct sustainable development benefit noted

$\checkmark$ - $\quad$ indirect sustainable development benefit noted

$\mathrm{NB}-\quad$ negligible sustainable development impact noted

Table 2. The Contributions of CDM's to Sustainable Development in Nigeria

\begin{tabular}{|c|c|c|c|c|c|c|c|c|}
\hline No. & Project & Project Summary & $\begin{array}{c}\text { Environ- } \\
\text { ment }\end{array}$ & Economic & Health & $\begin{array}{c}\text { Employ- } \\
\text { ment }\end{array}$ & $\begin{array}{c}\text { Tech } \\
\text { Transfer }\end{array}$ & $\begin{array}{l}\text { Other } \\
\text { social }\end{array}$ \\
\hline 1. & $\begin{array}{l}\text { Recovery of } \\
\text { associated gas that } \\
\text { would otherwise be } \\
\text { flared at Kwale oil- } \\
\text { gas processing plant, } \\
\text { Nigeria }\end{array}$ & $\begin{array}{l}\text { The capture and } \\
\text { utilisation of the majority } \\
\text { of associated gas } \\
\text { previously sent to flaring } \\
\text { at the Kwale plant } \\
\text { (Kwale OGPP) }\end{array}$ & レレ & $\checkmark$ & $\checkmark$ & $\checkmark$ & $\checkmark$ & NB \\
\hline 2. & $\begin{array}{l}\text { Pan Ocean Gas } \\
\text { Utilization Project }\end{array}$ & $\begin{array}{l}\text { The purpose of the } \\
\text { project is to eliminate gas } \\
\text { flaring at the Ovade- } \\
\text { Ogharefe oil field } \\
\text { operated by Pan Ocean } \\
\text { Oil Corporation (Nigeria) } \\
\text { in a Joint Venture } \\
\text { Partnership with Nigerian } \\
\text { National Petroleum } \\
\text { Corporation (NNPC). }\end{array}$ & レレ & $\checkmark$ & $\checkmark$ & $\checkmark$ & NB & NB \\
\hline 3. & $\begin{array}{l}\text { Efficient Fuel Wood } \\
\text { Stoves for Nigeria }\end{array}$ & $\begin{array}{l}\text { The purpose of the } \\
\text { project activity is the } \\
\text { dissemination of up to } \\
12,500 \text { efficient fuel } \\
\text { wood stoves (SAVE80) } \\
\text { and heat retaining } \\
\text { polypropylene boxes } \\
\text { (hereafter referred to as } \\
\text { the SAVE80 system) in } \\
\text { different states located in } \\
\text { the Guinea Savannah } \\
\text { Zone of Nigeria, at } \\
\text { subsidized prices. }\end{array}$ & レレ & $\checkmark$ & $\checkmark$ & NB & $\checkmark \checkmark$ & NB \\
\hline 4. & $\begin{array}{l}\text { Recovery of gas at the } \\
\text { /Umutu Field, Nigeria }\end{array}$ & $\begin{array}{l}\text { AThelppurpose of this } \\
\text { project activity is to } \\
\text { recover gas that is } \\
\text { currently, and in the } \\
\text { future would be, flared at } \\
\text { Asuokpu/Umutu } \\
\text { Marginal Field located in } \\
\text { block OML } 38 \text { in Nigeria } \\
\text { and to deliver it to the } \\
\text { domestic market for } \\
\text { productive use as an } \\
\text { energy product. }\end{array}$ & レレ & $\checkmark$ & $\checkmark$ & $\checkmark$ & $\checkmark$ & NB \\
\hline 5. & $\begin{array}{l}\text { Municipal Solid } \\
\text { Waste (MSW) } \\
\text { compositing facil }\end{array}$ & $\begin{array}{l}\text { The project activity } \\
\text { involves the production } \\
\text { of high quality compost } \\
\text { from Municipal Solid } \\
\text { Waste (MSW) by using } \\
\text { advanced composting } \\
\text { technology. }\end{array}$ & $\checkmark$ & $\checkmark$ & $\checkmark$ & $\checkmark$ & NB & NB \\
\hline
\end{tabular}

(Table 2 continued next page) 


\begin{tabular}{|c|c|c|c|c|c|c|c|c|}
\hline No. & Project & Project Summary & $\begin{array}{c}\text { Environ- } \\
\text { ment }\end{array}$ & Economic & Health & $\begin{array}{c}\text { Employ- } \\
\text { ment }\end{array}$ & $\begin{array}{c}\text { Tech } \\
\text { Transfer }\end{array}$ & $\begin{array}{l}\text { Other } \\
\text { social }\end{array}$ \\
\hline 6. & $\begin{array}{l}\text { Afam Combined } \\
\text { Cycle Gas Turbine } \\
\text { Power Project }\end{array}$ & $\begin{array}{l}\text { The "project activity", } \\
\text { called Afam VI ("the } \\
\text { project") is a } 650 \mathrm{MW} \\
\text { grid-connected combined } \\
\text { cycle gas turbine (CCGT) } \\
\text { fuelled by natural gas. }\end{array}$ & $\checkmark \checkmark$ & NB & $\checkmark$ & $\checkmark$ & NB & $\checkmark$ \\
\hline 7. & $\begin{array}{l}\text { LFG project in } \\
\text { Nigeria }\end{array}$ & $\begin{array}{l}\text { The project activity is to } \\
\text { build, operate and } \\
\text { maintain a landfill gas } \\
\text { collection and flaring } \\
\text { system on landfills in } \\
\text { Lagos. }\end{array}$ & レレ & NB & NB & $\checkmark$ & $\checkmark \checkmark$ & NB \\
\hline 8. & $\begin{array}{l}\text { Kainji Hydropower } \\
\text { Rehabilitation Project, } \\
\text { Nigeri }\end{array}$ & $\begin{array}{l}\text { The project covers the } \\
\text { rehabilitation of unit } 5,6 \\
\text { and } 12 \text { of the Kainji } \\
\text { Hydropower powerhouse. }\end{array}$ & $\checkmark \checkmark$ & $\checkmark$ & NB & $\checkmark$ & NB & $\checkmark$ \\
\hline 9. & $\begin{array}{l}\text { Lafarge WAPCO } \\
\text { Partial Substitution of } \\
\text { Alternative Fuels in } \\
\text { Cement Facilities } \\
\text { Project in Nigeria }\end{array}$ & $\begin{array}{l}\text { The project activity will } \\
\text { partially replace fossil } \\
\text { fuels used in pyro- } \\
\text { processing with lower } \\
\text { carbon alternative fuels, } \\
\text { primarily biomass } \\
\text { residue, thus resulting in } \\
\text { measurable reductions of } \\
\text { GHG (CO2) emissions in } \\
\text { Nigeria. }\end{array}$ & $\checkmark \checkmark$ & NB & NB & $\checkmark$ & NB & NB \\
\hline 10. & $\begin{array}{l}\text { Recovery and } \\
\text { Utilization of } \\
\text { Associated Gas from } \\
\text { the Obodugwa and } \\
\text { neighbouring oil fields } \\
\text { in Nigeria }\end{array}$ & $\begin{array}{l}\text { The purpose of this } \\
\text { project activity is to } \\
\text { implement the } \\
\text { infrastructure to allow for } \\
\text { the utilization of the } \\
\text { associated gas that is } \\
\text { currently flared from two } \\
\text { oil fields in OML } 561 \text { in } \\
\text { Delta State Nigeria } \\
\text { thereby reducing the } \\
\text { flaring of associated } \\
\text { natural gas and thus } \\
\text { emissions of CO2 into the } \\
\text { atmosphere. }\end{array}$ & レレ & NB & $\checkmark$ & $\checkmark$ & NB & $\checkmark$ \\
\hline
\end{tabular}

Source: CDM, (2016A); CDM, (2016B); CDM, (2016c); CDM, (2016d); CDM,(2016e); CDM, (2016f); CDM, (2016g); CDM, (2016h); CDM, (2016i); CDM, (2016j)

\section{Analysis of results}

- Environmental sustainable development: All projects in the sample showed a clear goal of reducing greenhouse gas emissions. The methods of reducing emission include the reduction in flaring as well as replacement of fossil fuels. The benefits were classified as direct for $90 \%$ of the projects since the primary objective of the projects was to reduce emissions

- Economic sustainable development: Approximately $60 \%$ of projects in the sample displayed some economic sustainable development. Of the $60 \%$ of projects that contained economic sustainable development goals all of them displayed indirect benefits. The economic benefits included increased productivity due to improved reliability of electric systems in respect of hydro power stations.

- Employment benefits: Approximately $90 \%$ of the projects displayed increased employment benefits. The employment benefits arise to the additional work required to implement the project, and such benefits were limited to the project area. All the employment benefits were indirect in nature and were a by-product of implementing GHG reducing technologies. 
- Health benefits: Approximately $70 \%$ of projects in the sample displayed some health benefits. All the health benefits were indirect in nature and usually stemmed from reduced air pollution levels.

- Technology transfer benefits: Approximately $40 \%$ of the sample displayed technology transfer benefits. Of the projects that displayed technology transfer benefits only, 50\% showed direct technology transfer benefits. Technology transfer benefits included improved heating technology in respect of food for poverty stricken homes as well as alternative energy technologies such as hydropower stations.

- Other social benefits: Approximately 30\% of the sample displayed other social benefits. All the social benefits were classified as indirect benefits from the project. Social benefits include improving the reliability of the electricity supply for households as well as improving overall access to electricity for the people of Nigeria.

Per a review of the above, it is clear that CDM projects in Nigeria are heavily skewed in favour of greenhouse gas reductions. The by-products of the implementation of technologies to reduce greenhouse gas reductions are increased employment benefits and economic sustainable development benefits. The employment benefits arise out of employment of skilled staff which is required to manage and implement the project as well as infrastructure development which would also require construction work being performed. They are thus seen as indirect benefits arising from the projects.

The economic sustainable development analysis shown above does not consider any economic gains from the sale of future CER's since this is an uncertain event. The health benefits are seen as indirect and long term in relation to the projects and the technology transfer benefits are minimal in most projects. CDM projects clearly appear to be lacking in social benefits, since only $30 \%$ of the sample displayed any social benefits for the community in which they were housed. An overall conclusion from the analysis above is that CDM projects in Nigeria are focused on emissions reduction with economic and social implications being secondary by products from the focus area.

\section{Policy futures for CDM projects in Nigeria}

Policy futures for CDM projects in Nigeria may include two alternatives. A first alternative would the establishment of international benchmark standards in respect of sustainable development. An example would be that a project must generate some local infrastructure development as well as generate a certain level of employment in the project area. A second alternative could include the generation of an international list of sustainable development benefits which could be amended by individual countries for circumstances or situations within their countries. (Boyd et al., 2009) The first alternative could work in Nigeria provided the benchmarks are both realistic and complete. The second alternative would require a considerable amount of effort and cooperation between countries since they would be required to mutually agree on a comprehensive list of sustainable development benefits. Since the second alternative would not wholly be within the control of the Government of Nigeria it would seem that the first alternative would be easier to implement in the short term.

\section{LIMITATIONS AND FUTURE RESEARCH}

The sustainable development benefits of CDM projects were evaluated exclusively through an examination of the supporting project design documents. Since the information in some parts of the PDD's maybe incomplete and certain views contained in the PDD's maybe biased or subjective, the results from an analysis of such documents may be less objective. Given the duration of project life cycles no subsequent evaluation was performed to determine the accuracy of the baseline targets in the PDD. A study which focuses on a subsequent evaluation of a project against targets in the PDD could be performed to determine the effectiveness of CDM contributions to sustainable development.

\section{CONCLUSION}

The overview of CDM projects globally confirms that CDM projects to contribute to environmental sustainable development through the reduction of greenhouse gases. Per an analysis of the value of CER's relative to regional GDP, it is confirmed that CDM also contribute to regional economic sustainable development. From an international perspective, it can thus be concluded that CDM contributes to both economic and environmental sustainable development. 
In terms of the CDM project distribution in Nigeria by project type approximately $59 \%$ of projects are focused on emission reductions and landfill gas projects. This result supports the detailed testing of PDD's which confirm most CDM projects focus primarily on GHG reductions with little or no attention to economic and welfare benefits. In terms of CDM project distribution by project type, it is observed that $42 \%$ of CDM projects in Nigeria are in the Delta region and another $34 \%$ are located in Lagos and the Rivers regions. Thus in total $76 \%$ of all projects will only benefit three regions in Nigeria. The uneven distribution of CDM projects in Nigeria both by region and project type place a doubt on the ability of projects to contribute materially to sustainable development for the country as a whole.

Detailed testing of CDM projects via the PDD review indicates that GHG emission reduction remains a primary objective of all CDM projects. Other sustainable development outcomes such as health benefits, technology transfer, employment and economic sustainable development remain secondary by products of the investment in GHG reducing technologies. In order for CDM projects to contribute more significantly to sustainable development, objectives they will have to include more economic and welfare based objectives such as direct employment generation and education and housing benefits. The policy futures noted above are feasible and should be considered seriously if CDM projects are to contribute materially toward sustainable development in Nigeria.

\section{AUTHOR INFORMATION}

Dr. Surendran S. Pillay is the Coordinator of Accounting Programs at the University of Kwa-Zulu Natal in South Africa's Westville Campus and holds a Ph.D. in taxation. He is also a qualified Chartered Accountant (SA). Email: pillays18@ukzn.ac.za

\section{REFERENCES}

Anon, (2015). The Three Pillars of Sustainable Development. Available: http://www.thwink.org/sustain/glossary/ ThreePillarsOfSustainability.htm Date of Access 19 November 2015.

Boyd, E., Hultman, N., Timmons Roberts, J., Corbera, E., Cole, J., Bozmoski, A., \& Liverman, D. M. (2009). Reforming the CDM for sustainable development: lessons learned and policy futures. Environmental Science \& Policy, 12(7), 820831.

Bramley, G., Dempsey, N., Power, S., \& Brown, C. (2006, April). What is 'social sustainability', and how do our existing urban forms perform in nurturing it. In Sustainable Communities and Green Futures' Conference, Bartlett School of Planning, University College London, London.

Brundtland, G., Khalid, M., Agnelli, S., Al-Athel, S., Chidzero, B., Fadika, L., ... Okita, S. (1987). Our Common Future ('Brundtland report').

CDM, (2015). CDM Pipeline report. Available: http://www.cdmpipeline.org/ Date of Access 17 November 2015

CDM, (2015a). Register a project activity https://cdm.unfccc.int/Projects/pac/howto/CDMProjectActivity/Register/ index.html Date of Access 27 November 2015

CDM, (2015b). Guidelines for completing CDM-PDD; CDM-NBM and CDM-NMM. Available: http://cdm.unfccc.int/Reference/Documents/Guidel_Pdd/English/Guidelines_CDMPDD_NMB_NMM.pdf Date of access:12 December 2015

CDM (2016A). "Project Design Document: Recovery of associated gas that would otherwise be flared at Kwale oil-gas processing plant, Nigeria" Available: https://cdm.unfccc.int/filestorage/T/2/N/ T2N9G73GCSUW91EJUE7BJRW9NGIOLU/ Final\%20PDDNigeria\%20_03_08_06.pdf?t=R118b2JvbjY4fDC0r5W1PIrzGoM9z5uV2O0S Date of Access: 10 August 2016

CDM (2016B). "Project design document form: Pan Ocean Gas Utilization Project." Available: https://cdm.unfccc.int/filestorage/S/H/Z/SHZ1DGJ0EP4C3XIMRA9UF5QWVLTO6Y/031115_Revised\%20PDD\%20 clean\%20copy\%20VVS.pdf?t=cFZ8b2JvbjlofDDvAW0kUkSYd4OnPRA3ktBz Date of Access: 10 August 2016

CDM (2016c). Project design document form: Efficient Fuel Wood Stoves for Nigeria" Available: https://cdm.unfecc.int/filestorage/1/z/23VFX68ADZ9LMN1RU4WPEIOSYGB5H7.pdf/130218_Nigeria_PDD_form02 _v03_PRC_clean.pdf?t=bDF8b2JvcHpnfDD5mnvF8h6tmm6u1GysZa1y Date of Access: 10 August 2016

CDM (2016d). "Project design document form: Recovery and marketing of gas that would otherwise be flared at the Asuokpu/Umutu Marginal Field, Nigeria” Available: https://cdm.unfccc.int/filestorage/R/O/V/ ROV9E0UTKSJFND2IW7AB13Y546GPCM/PDD\%20Version\%201.9?t=YXJ8b2JvcTNkfDBRxzxrZGT5RdUO15h4-LC Date of Access: 10 August 2016

CDM, (2016e). "Project design document form: Municipal Solid Waste (MSW) Composting Project in Ikorodu, Lagos State" Available: https://cdm.unfccc.int/filestorage/1/E/V/

1EVFRS23DUIJPHK85N6QCX9BT40AGY/PA3841_Earthcare_PDDv6_22Dec2015.pdf?t=Tkt8b2JvcTZ6fDDNvS- 
SPOCma4WcDxMr3JB3 Date of Access: 10 August 2016

CDM, (2016f). "Project design document form: Afam Combined Cycle Gas Turbine Power Project." Available: https://cdm.unfccc.int/filestorage/S/B/1/SB14NR3HV8QULO5WGC67I9MDZETXK2/230215\%20PDD\%20Marked\% 20Changes\%20now\%20in\%20VVS\%20template_Public_clean.pdf?t=R218b2JvcT10fDAaApRURZfZ1GhBWYed30qt Date of Access: 10 August 2016

CDM, (2016g). "Project design document form: LFG project in Nigeria" Available: https://cdm.unfccc.int/filestorage/4/s/YI6CGF0E7VM31JASRZXKQDWULB8OHT.pdf/PDD\%20of\%20LFG\%20proj ect\%20in\%20Nigeria.pdf?t=ZDJ8b2JvcWNvfDCQIXdqUsXeJDu5ruPfhh3q Date of Access: 10 August 2016

CDM, (2016h). "Project design document form: Kainji Hydropower Rehabilitation Project, Nigeria" Available: http://cdm.unfccc.int/filestorage/u/q/6UQ72R4GL19SC0EPOJFZAT83NXHDYB.pdf/PDD_Kanji_121220.pdf?t=WH B8b2JvcjJpfDBU9NUaNB5K_6WQAps3VMel Date of Access: 10 August 2016

CDM, (2016i). "Project design document form: Lafarge WAPCO Partial Substitution of Alternative Fuels in Cement Facilities Project in Nigeria" Available: https://cdm.unfccc.int/filestorage/i/a/ADR6SP3COM0F7H5BGW1J4QN2UIVE9L.pdf/F\%20181212\%20Lafarge\%20 Master\%20PDD\%206\%20PDF.pdf?t=WWx8b2JvcjZtfDD0t6hkBryTLjGKGEufKSzf Date of Access: 10 August 2016

CDM, (2016j). "Project design document form: Recovery and Utilization of Associated Gas from the Obodugwa and neighbouring oil fields in Nigeria" https://cdm.unfccc.int/filestorage/o/q/LTE4YOD03G6N5CX8HRZUA9SKJP2VMB.pdf/P\%20081112\%20Final\%200 bodugwa\%20PDD\%20public\%20vers.pdf?t=TGt8b2JvcmJmfDDUqESM1LtUEF2Za_ybPEKR Date of Access: 10 August 2016

DEAT. (2010).“Kyoto Protocol \& the Clean Development Mechanism”. Available: http://www.environment.gov.za/ClimateChange2005/Kyoto_Protocol.htm Date of Access 28 August 2010.

Dechezleprêtre, A., Glachant, M., \& Ménière, Y. (2008). The Clean Development Mechanism and the international diffusion of technologies: An empirical study. Energy Policy, 36(4), 1273-1283.

EC, (2015). CO2 times series 1990-2013 per capital for World Countries. http://edgar.jrc.ec.europa.eu/overview.php?v=CO2ts_pc1990-2013\&sort=des9 Date of Access 17 November 2015

EC (2015a). The EU Emissions Trading System. Available:http://ec.europa.eu/clima/policies/ets/index_en.htm Date of Access 19 November 2015

Gilbertson, T. \& Reyes, O. (2009). "Carbon Trading: How it works and why it fails." Critical Currents. Dag Hammerskjold Foundation. Occasional paper series, 7:9-10, November.

Lecocq, F., \&Ambrosi, P. (2007). "The clean development mechanism: History, status, and prospects". Review of Environmental Economics and Policy, 1(1), 134-151.

Metcalf, G. E., \& Weisbach, D. (2009). Design of a Carbon Tax, The. Harv. Envtl. L. Rev., 33, 499.

Newport, D., Chesnes, T., \& Lindner, A. (2003). The "environmental sustainability" problem: ensuring that sustainability stands on three legs. International Journal of Sustainability in Higher Education, 4(4), 357-363.

NG, (2015). Climate Change Nigeria. Available: http://climatechange.gov.ng/about-us/ Date of Access 11 November 2015

Paulsson, E. (2009). A review of the CDM literature: from fine-tuning to critical scrutiny? International environmental agreements: politics, law and economics, 9(1), 63-80.

Pillay, S., \& Buys, P. W. (2013). Carbon Tax Pricing And The Social Cost Of Carbon: The Case In The South African Motor Vehicle Manufacturing Industry. Journal of Applied Business Research (JABR), 29(6), 1751-1762.

Pillay, S. (2015). The Impact Of Clean Development Mechanism Projects On Sustainable Development In South Africa. International Business \& Economics Research Journal (IBER), 14(6), 777-790.

Rai, V. (2009). "Promoting Clean Development". Harvard International Review, 31(3), 70-75. Fall.

Santilli, M., Moutinho, P., Schwartzman, S., Nepstad, D., Curran, L., \& Nobre, C. (2005). Tropical deforestation and the Kyoto Protocol. Climatic Change,71(3), 267-276.

Sutter, C., \& Parreño, J. C. (2007). Does the current Clean Development Mechanism (CDM) deliver its sustainable development claim? An analysis of officially registered CDM projects.Climatic change, 84(1), 75-90.

Sirohi, S. (2007). CDM: Is it a 'win-win' strategy for rural poverty alleviation in India? Climatic Change, 84(1), 91-110

Treck, C. (2004). New partnerships in global environmental policy: The Clean Development Mechanism. The Journal of Environment \& Development, 13(3), 295-322.

UNFCCC. (2004). “A National Climate Change Response Strategy for South Africa”. Available: http://unfccc.int/files/meetings/seminar/application/pdf/sem_sup3_south_africa.pdf Date of Access 12 September 2010.

UNFCCC, (2015). Status of Ratification of the Convention Available: http://unfccc.int/essential_background/convention/status_of_ratification/items/2631.php Date of Access 11 November 2015.

UNFCCC, (2015a). List of Non Annex 1 Parties to the Convention. Available: http://unfccc.int/parties_and_observers/parties/non_annex_i/items/2833.php Date of Access 11 November 2015

UNFCCC, (2015b). Kyoto Protocol. Date of Access 11 November 2015 http://unfccc.int/kyoto_protocol/items/2830.php

Von Stein, J. (2008). The international law and politics of climate change ratification of the United Nations Framework Convention and the Kyoto Protocol. Journal of Conflict Resolution, 52(2), 243-268. 
Wang, C., Zhang, W., Cai, W., \& Xie, X. (2013). Employment impacts of CDM projects in China's power sector. Energy policy, 59, 481-491.

Worldbank (2015a). What is sustainable development. Available: http://www.worldbank.org/depweb/english/sd.html Date of Access:19.11.2015

Worldbank, (2015). "Data: Nigeria." Available: http://data.worldbank.org/country/nigeria Date of Access 17 November 2015

Woerdman, E. (2000). Implementing the Kyoto protocol: why JI and CDM show more promise than international emissions trading. Energy Policy, 28(1), 29-38

Zomer, R. J., Trabucco, A., Bossio, D. A., \& Verchot, L. V. (2008). Climate change mitigation: A spatial analysis of global land suitability for clean development mechanism afforestation and reforestation. Agriculture, ecosystems \& environment, 126(1), 67-80. 


\section{NOTES}

